\title{
Cervical screening in general practice: a "new" scenario
}

\author{
Jane Chomet, Julian Chomet
}

\section{The new scheme}

For many years government policy on remunerating general practitioners for taking smears was to pay for smears taken from women aged 35 or older. Only one smear between each successive fifth birthday qualified for payment. Smears taken from younger women qualified for payment only if the woman had had three pregnancies.

One of the aims of the new contract is to increase the uptake of cervical screening in women aged 25-64, who will be called for screening at intervals of five and a half years. There are two targets offering different rates of payment, a higher one if general practitioners manage to take smears from $80 \%$ of women in this age group and a lower payment if they reach $50 \%$; there is no payment if the lower target is not reached. The difference in payment between the $50 \%$ target and the $80 \%$ target is substantial, so just missing the bull's eye can be very costly. The table shows an example of payments to a practice with 430 women in its target population.

Example of payment under new contract

\begin{tabular}{|c|c|c|c|}
\hline \multirow[b]{2}{*}{ Target population } & \multirow[b]{2}{*}{$\begin{array}{l}\text { Percentage (No) } \\
\text { smeared }(n=430)\end{array}$} & \multicolumn{2}{|c|}{ Payment to doctors $(£)^{\star}$} \\
\hline & & $\begin{array}{c}\text { From 1 April } \\
1990\end{array}$ & $\begin{array}{l}\text { From 1 April } \\
1991\end{array}$ \\
\hline \multirow[t]{2}{*}{$\begin{array}{l}\text { Women aged 25-64 } \\
\text { in England (21-60 } \\
\text { in Scotland) }\end{array}$} & $\begin{array}{c}<50 \%(<215) \\
50 \%-<80 \% \\
(215-343) \\
\geq 80 \%(\geq 344)\end{array}$ & $\begin{array}{r}0 \\
734\end{array}$ & $\begin{array}{r}0 \\
760\end{array}$ \\
\hline & $\geqslant 80 \%(\geqslant 344)$ & 2202 & 2280 \\
\hline
\end{tabular}

*Details of the complex calculations of targets and payments are contained in the family practitioner committee statement of fees and allowances, paragraphs 28.1 to 28.13 .

To qualify for payment, smears must have been performed on patients on the general practitioner's list and taken by any member of the practice who has been trained to take smears, including doctors, nurses, and locum doctors acting on behalf of the practice. Smears taken outside the practice by other authorities do count towards the target payment.

At present each practitioner must reach the targets on his or her list irrespective of the targets of other partners in the practice, but this may be changed to allow other partners' smears to be counted together towards the target. The family practitioner committee will request the general practitioner to provide details of smears performed on his or her patients, irrespective of where the smears were taken.

\section{Setting up a screening service}

General practitioners should aim to identify, reach, invite, and screen the eligible female population on their practice lists. ${ }^{1}$ The target population can be identified from an age-sex register or a register held on the practice's computer. The family practitioner committee can provide names with details of the history of smears if these are not already in the practice system. It is then necessary to set up the cervical smear register to enable quarterly additions and deletions of the changing cohorts of women and to update smear details on those already in the system. This can be done using a Kardex system or a computer. Each eligible

\section{Target groups}

From 1 April 1990: women born between 2 April 1925 and 1 July 1965 inclusive.

From 1 July 1990: women born between 2 April 1925 and 1 July 1925 will be excluded from the target and women born between 2 April 1965 and 1 July 1965 will be included; subsequently, each quarter an older cohort will leave the target population and a new younger cohort will enter it.

Exclusions: women who have had a hysterectomy (general practitioners will need to notify the family practitioner committee that such patients on their lists are ineligible for "clinical reasons"); and patients who are registered temporarily.

woman should have her surname, forename, date of birth, address, and smear details on this card or on a computer entry. Smear details should include date of sampling, name of laboratory, slide number, date of reporting by the laboratory, result, and date of next recall. All ineligible women (including those who have moved away from the area) need to be identified and deleted from the practice target, and the family practitioner committee should be informed of such actions.

Flagging or tagging records of patients who are on the cervical screening register is a useful technique in helping to identify other patients who have slipped through the net. It also helps in removing patients' names from the register when they move away from the practice.

The administration and documentation aspects of the smear register should be familiar to at least three members of staff but run mainly by one of them. This system allows good continuity: if one member is away then another can step in.

Ideally, doctors and nurses should be specially trained to take adequate smears and perform pelvic examinations at the same time. In addition, a good knowledge of family planning and contraception and well woman screening procedures, coupled with a good knowledge of menopausal and postmenopausal problems, is important.

Accommodation and equipment should include suitably equipped rooms that are warm, clean, well ventilated, and well lit and that provide privacy and have comfortable couches. There should be a suitable supply of equipment including spatulas, endocervical brushes, speculums, and sterilising facilities. The delivery system for transport of slides to and from the laboratory and the purchasing, ordering, and reordering of disposable items and their storage and distribution in the practice must be carefully organised. Good liaison with the laboratory is an important part of the process.

\section{Who should be screened in an ideal service?}

A woman should have her first smear taken within a year of first having sexual intercourse, and smears should continue at three year intervals (or earlier if suggested by the cytologist or if the woman is at high
Correspondence to: $\mathrm{Dr}$ BrMed J 1990;300:1504-6 
risk). Taking smears can stop if a wowan has had three consecutire negative smears leading up to her 70 h h birthday and if she no longer has sexual intercourse. Women over the of 70 who are sexully active should continue to have regular smears.

Squamous cell carcinoma is the predominant type found in cervical cancer. It is associated with being or having been sexually active and therefore untikely to be present in virgins. Howrever, virgins can bave a mucts rarer variety of cervical cancer, adtenocarcinoma, which is mostly found in women aged 60 to 70 . It is vital that virginal vromen have a smear if they experience any unusual raginal discharge or bleeding from the genital tract as this can be a sign of carncer anywhere in the genieal tract.

\section{Getiing petiens to the sengery}

The wording of invitations to women due for a smaear needs to be carefully thought out to enable theon to understand the imaportance and benefit of being screened at regular intervals and to encourage other women to do the same. An inviration that has met with some success is one that coincides with a woman's birthdy and is sent as a congratulations card offering a well roman check as a "birthday present" from the practice. Each invitation contarins a definite appointment bate (which should be entered in the appointments book) and requires the patient to confium thar she is coming or to contact the practice to change the date. The envelope containing the information should be stamped with the practice's mame and address so that the letter can be returned if the patient has gone awray or changed address. This also helps to identify those patients lost to follow up. This invitation technique of a ready booked appointment is more likety to trigger some kind of positive response than simply a recall invitation, which the parient may pus off indefinitety.

\section{Offering and reconding smears}

When a woman of appropriate age newly registers with the practice the doctor should take a full case bistory, identify the date and resutt of the last smear, and enter the parient into the smear register whether she is due for a smear or not. If the parient is due for a smear, offer to perform one straight away or make a firm appointment for one to be done in the near furure.

A woman antending for reasons unconnected with cervical cytology should have the date of her last smear checked and if appropriare be offered a smear on the spot or a future appoinument. The details should be entered in the register or computer and the patient's record fleded. Opportunistic cervical smears can also be offered during health promotion clinics for women such as a well woman ctinic of preconceptual planning service or a hormone reptacement therapy clinic.

Smear detrils should be entered into a register that includes the perient's full name, date of birth, date of smear, which member of the practice performed the smear, and the address to which to send the result. The smear should have a serial number, which should also be written on the smear report form: thus when the results are returned they can then be easily entered into the register as well as the patient's records. A regular check through the register will also show which results bave not come back.

Slides should be bbelled with the patient's surname, forename, and date of birth and the date the smear was taken. Accompanying forms should also have the paicen's address, date of bst menstrual period, and reterant history of hormones given, contraception, and cervical intrapithetil neoplasia, if any. These details are important to the cytologist, who sees the cells and not the parient and vet has to make recommendations for recall.

\section{Informing women of thair resuls:}

Women should alurays be informed of their smear results. Parients should be given a date by which to expect written notificarion of their reswits After this dare they should call the surgery if the results have failed to arrive. The parient's present aditress should have been registered at the time of taking the smear and an addressed, stamped enretope left in her reconds. The envetope should atso bear the prantice's address in case the parient suddienty changes her adiress without notifxing the practice amd the result faits to reach her.

The format and conterat of the results need careful wording. If the result is mormal it stould be clemty and immediarely stated that "The resuli of your cervical smear taken on ... shoured NO Evidence OF CANCER." This should be followed by a dare on which the patient should book an appointraent or the practice will send for her.

If the result is abnormal bur not precancerous (for example, due to thrush or inflammation) ibe leter can begin similarly and then inctude the exact mording of the laboratory report followred by an explmation of what the wrords actually mean. If the smear is positive a similar explanation should be given, along with a request for the patient to see the doctor and have the results properiy explained and follow up action taken.

\section{Problems ix meeting the torget}

Theremay bean inflation of the general practitioner's target as a resuly of wromen who are on the list bun who have changed their address and cannor be traced by the general practitioner. Smears baten outside the practice (at hospitals, private ctinics, the workplace, or other screening services) will reduce the effective target still further. Women who refuse to have smears (inchuting virgins, those who are afraid or emberrassed (especintly in the presence of male doctors), or those who betiere themselves to be immune to the disease) pose further problems in meeting the target.

\section{Senears pexformed for no remeneration}

Smears for which the general practitioner receives no remuneration inctude those on woreen within the target group who will need more frequent smears, at intervals of three years or less; on women outside tanget groups who are under 25 years or over 64 years and who are at risk and need to be smeared (see box for recall recommendations); and on temporary perients, who present a mobile at risk group and who mery be bost to recall and follow up. Such women should be offered opportunistic smears when they presen as temporary residents at the surgery for whaterer reason. At present, one in $\mathbf{2 0}$ smears taken in oenr north Londra practice are from temporary parienes, which indicanes a large group of migrating patients at risk.

Furthermore, if a smear is described as "indequate" as a result of there being too few cells for the crtologist

\section{Approximate time requined per polien per} smear

Booking, an appointment

Taking a smear in the practice

Administration, processing, documentarion

15 mimutes

Laboratory processing and documentontion 90 mineres

Processing result on its return to the practice 8 mimeses 
Rescit of eervical smear Recommendation

Inadequate specimen (lack of Repeat smear immedianch cells, unclear smear, air dried smear

Normal smear; endocervical Recall in three vears; recall in cone ver if: first ever cells present smear in postmenopausal anom; previonis smear reported as abnormal, posirive, infmmantory, or dyskarvotic; previoasty treation oerrical iniracpithelial neoplasia; genital merts present on patient or partner; promiscuous sexald bistory of either partner, particularty if drug is involved; immunosuppressive treatmant giver bysterectomy for cervical maliznancr; theary maker (>20 cigarettes per day )

Normal smear: no endocervical calls present Irfilammatory smear Recall in one vear

Treat infective onganism in anticas and check for presence in partner; repeat smear within one year after treatment.

Persistent infammation Refer for colposcopy (one in fre mod smears may hide cervical intracpithelial meeplosia)

Arypacal smear

Repeat smear in six months: if persistent, refer for colposcopy

Arrophic smear

Indicates oestrogen deficiency (bormaone replacement therapy may be needed). Recall in three years. If atrophic changes are severe trea with oestrogen (10 $\mathrm{\mu g}$ ethinyloestradiol orally for 10 days); repeat smear after treatment. If atre chic changes persist, refer for colposcopy (changes lide or be a sign of cervical carcinoma

Dyskarvotic smear (mild, All dyskaryotic smears should be referred (urenth moderate, sewere)

Carcinoma in situ

Endometrial cells

Gandular endocervical cells Gtandutar neoplasia

Herpesvirus

Human papillomarirus (wan virus) too late to include them for submission in his or her target results. Abnormal or positive smears may take longer to be reported because they may be examined by three people in the laboratory, which on lead to further delax.

Recall suggested by the cytologist will often be more frequent than that qualifying for target payments; these smears are done solety for the benefir of the patient with no remuneration involved.

\section{Cessorion of recall}

There is no need to recall a patient who has hod a hrsterectomy for a non-malignant condition if before that hysterectomy she had a normal smear and if the removed uterus and appendages were also non-malignont. Recall can atso cease in a woman of 65 vears and clder if she has ceased having sexul intercourse and since the cescation has had three consecutive negative cunears, the most recent one being in the previous three years, and if she has no undiagnosed irregular vaginal blecting. There is no upper age limit for screening a woman who bas never had a cervical smear.

\section{Concinsion}

The difficulties is setting up an efficient screening service and reaching the practice targets means that mony zeneral practitioners will be unable to moet the gowernment targets for payments for smears. Yet these eneral practitioners may still be performing many smears and providing a valuable service for which they will now find themeetves out of pocket in comparison with their remumeration before the target payments were immoduced

Given that a screening service oosts the practice a great deal in terms of time and money, the new targets may act as a disincentive to some general practitioners, who reacon that they will be unable to reach the new targets and therefore will not bother to perform any cervical screening at all. The situation could be improved by paying general practitioners for all smears performed, with bonus incentive payments given to general practitioners who manage to reach the two larget tiers curnently suggested.

The government is to be applauded for trving to improwe the efficiency of the cervical screening service, but whether penal practitioners-and, most imporconty, the parients - actualty benefit in the long run nemains to be seen.

1. Chomed 3, Chumel J. Cervical cancer. Wellimgterangh: Thorsuns, 1969.

\section{THE MEMOIR CLUB}

It has become the fashion to concentrate attention on people who show recurrent social failure. These people deserve our help, but they are, relativety speaking, a dull lor, providing little scope for profrtable prttern analysis. At the same time fashion dictates that we should look with something approaching scom on the successful achievers. This is bad natural history and bed social science. First, effective compassion can only be built on a great body of positive achievement. This achievement provides the bricks and mortar for all effective humanitarian action. Secoundty, the whote of human progress depends on striving after excellence in an infwite variety of areas. It is thus both more interestiog and more useful to structy the natural bistory of those who bave made or are making a major contribution to humaniry. The achievers show up their characteristics much more clearty than do the passive, the enfeebled, and the opters out.

At one point in my career I was able to identify a small but coherent group of manifest achievers. As under secretary of state for commonwealth rebations and colonies in Harcld Witson's first government, it was part of my job to met and see off visiting commonwealth premiers and prime ministers at London Airpor, so 1 had many good opportunities for gossiping with the great. I soon found that whereas premiers and prime ministers sart ereats in interests, intellizence, and education, they have three things in common-energy, tounghness, and a detight in talking about themetues. So the long hours passed pleasantly enough and I learnt a good deal about the bolding and exercising of power.

of 1 ry collection of approximatety 20 commomwealth premiers and prime mivisters, three were doctors (1wo of them gencral practitioners and one an cubopacdic surgeon), over balf were bwyers, and a third had been university teachers. Thongh some were excectiongty intelligent, all except one found it wisest to bide their light under a buribel. Political leaders are atmost atways selected by their colleazues, and polinicians are suspicious of choosing those they convider "too dever by balf."

From A Aatured Histary of Evendory Life: A Bicgraphical Gride for Would-be Docuars of Secien by Lard Taylor of Harkw. Publisted under the BMY's Memoir Chub imorim. ISBN 072790242 3. Price: Inband f19.95; abroad E24.C0; USA 540.00. BMA mesober: Intand 118.95; abroad £23.00; USA $\$ 38.00$. 